\title{
Supratrochlear Foramen: Incidence, Importance and Clinical Implications in North-Indian Population
}

\author{
Bhumica Dang ${ }^{1}$, Vivek S. Malik ${ }^{2}$, Priyanka Parmar ${ }^{3}$.
}

${ }^{1}$ Demonstrator, Department of Anatomy, Pt. B.D. Sharma PGIMS, Rohtak, Haryana, India.

${ }^{* 2}$ Associate Professor, Department of Anatomy, Pt. B.D.Sharma PGIM S, Rohtak, Haryana, India.

${ }^{3}$ Demonstrator, Department of Anatomy, Pt. B.D. Sharma PGIMS, Rohtak, Haryana, India.

\section{ABSTRACT}

Supratrochlear foramen (STF) is a variation noted in the lower end of humerus in humans. This variation is clinically significant in treatment of supracondylar fractures. The study was done to find the incidence and dimension of supratrochlear foramen in 100 dried humeri of unknown sex and age, obtained from Pt. B.D. Sharma PGIM S, Rohtak.The STF was measured using digital verniercaliper.In our study,supratrochlear foramen ( STF) was seen in 30 out of 100 cases of humeri ( incidence $30 \%$ ), round shape more common, and present more frequently on the left side.Translucency of the septum has beennoted in the $30 \%$ of the humeri. The knowledge is of importance for orthopaedic surgeons and radiologists in clinical practice.

KEY WORDS: Humerus, Supratrochlear foramen, Supracondylar fractures.

Address for correspondence: Dr. Vivek S. Malik, Associate Professor, Department of Anatomy, Pt. B.D.Sharma PGIM S, Rohtak, Haryana, India. E-Mail: vivekmalik98@ gmail.com

\begin{tabular}{|c|c|}
\hline \multicolumn{2}{|r|}{ Online Access and Article Informtaion } \\
\hline 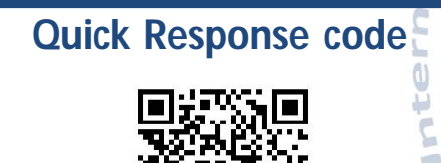 & $\begin{array}{c}\text { International Journal of Integrative Medical Sciences } \\
\text { www.imedsciences.com }\end{array}$ \\
\hline 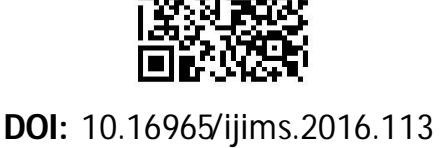 & $\begin{array}{ll}\text { Received: 04-04-2016 } & \text { Accepted: 19-04-2016 } \\
\text { Reviewed: 04-04-2016 } & \text { Published: 10-05-2016 }\end{array}$ \\
\hline Source of Funding: Self & Conflicts of interest: None \\
\hline
\end{tabular}

\section{BACKGROUND}

The supratrochlear foramen (STF) is an important and rarely mentioned anatomical variation in the lower end of humerus.Coronoid- Olecranon septum (COS) refers to the lamina of bone present between the olecranon fossa and coronoid fossa. The septum may be opaque, translucent or perforated forming supratrochlear foramen. The supratrochlear foramen was first described by Meckel in 1825 [1], since then it was described in various animals like dogs, hyenas, cattle and other primates [2,3]. Because of this STF, the person may be able to overextend the joint [4]. Studies have shown that humerus is not perforated in foetal stage [5]. The septum is present till 7 years of age, after which it becomes occasionally absorbed to form STF
$[6,7]$. Generally the shapes of STF are round, oval and triangular $[8,9]$. Since the supracondylar fractures are quite common in the pediatric age group and for intra-medullary pinning detailed knowledge of the variations in the distal end of the humerus is significant. The humerus may be evaluated radiologically for any pathologic lesions and abnormal cysts $[10,11]$. Knowledge of the anatomicalvariations is always important to assist in a correct radiological investigation. The findings of the present study willbenefit the orthopaedic surgeons, radiologists and anthropologists.

\section{MATERIALS AND METHODS}

The aim of the research study was to find out various aspects of supratrochlear foramen. A total of 100 dried(46 right sided and 54 left 
sided) adult humanhumeri of unknown sex and age were obtained from the Department of Anatomy, Pt. B.D. Sharma PGIM S, Rohtak.The bones were selected free of any pathological changes. The digital verniercaliper with minimum scale of $0.01 \mathrm{~mm}$ was used to take the measurement.

Following parameters were studied:

1. Incidence of STF.

2. Morphometric dimensions as Maximum Vertical Diameter ( V.D.) and Maximum Transverse Diameter ( T.D.)

3. Shape of STF

4. Presence / Absence of translucency of the septum.

\section{OBSERVATIONS AND RESULTS:}

STF was seen in $30 \%(n=30)$ of bones out of 100 bones studied. STF was observed in 12 cases on the right side and 18 cases on the left side.

Table 1: Frequency of Supratrochlear Foramen (STF) in humeri.

\begin{tabular}{|c|c|c|}
\hline Side of humeri & $\begin{array}{c}\text { STF present } \\
\text { (n=30 out of } \mathbf{1 0 0} \\
\text { humeri) }\end{array}$ & Percentage \\
\hline Right & $12 / 46$ & $26.09 \%$ \\
\hline Left & $18 / 54$ & $33.33 \%$ \\
\hline
\end{tabular}

Most common shape of STF was round in 18 out of 30 humeri with STF, followed by oval in 12 humeri. No triangular or sieve like shape was observed.

Table 2: Shape of Supratrochlear Foramen (STF).

\begin{tabular}{|c|c|c|}
\hline Shape of STF & $\begin{array}{c}\text { Right }(\mathbf{n = 1 2} \text { with } \\
\text { STF) }\end{array}$ & $\begin{array}{c}\text { Left ( } \mathbf{n = 1 8} \text { with } \\
\text { STF) }\end{array}$ \\
\hline Oval & $4(33.33 \%)$ & $8(44.44 \%)$ \\
\hline Round & $8(66.66 \%)$ & $10(55.55 \%)$ \\
\hline Triangular & 0 & 0 \\
\hline Sieve & 0 & 0 \\
\hline
\end{tabular}

Fig. 1: Photograph of humeri showing STF $s$ of round and oval shape.

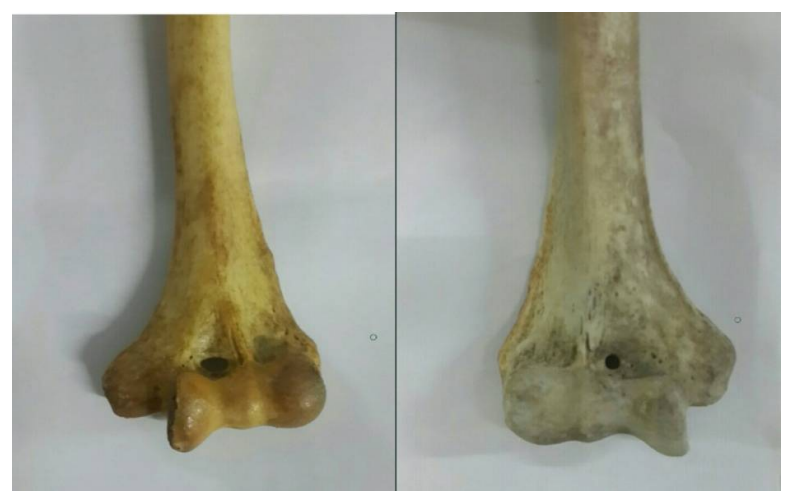

Int J Intg M ed Sci 2016;3(4):265-69. ISSN 2394 - 4137
Fig. 2: Photograph showing opaque and transluscentsupratrochlear septum.

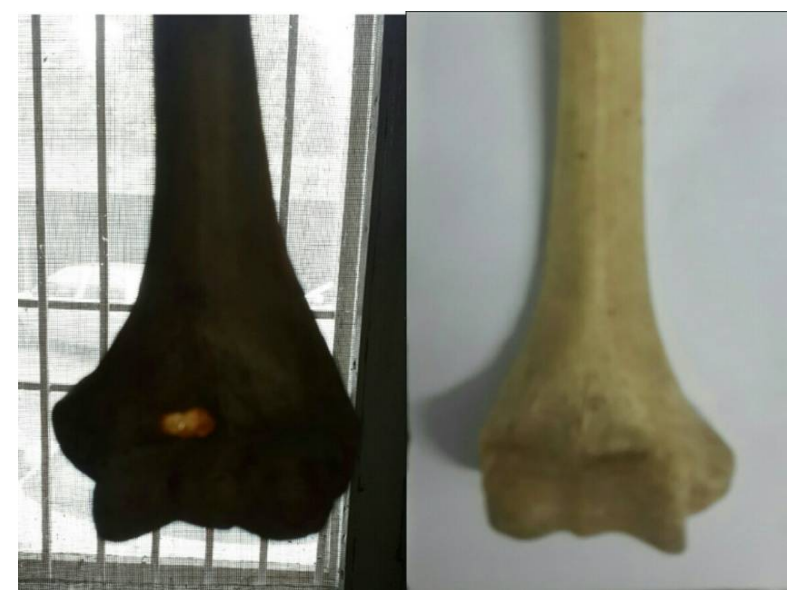

Out of the bones showing no STF, Translucent septum was found in 30(42.85\%) humeri. \{M ost commonly seen on right side: 18 cases $(52.94 \%)$ \}. Opaque septum was seen in $40(57.14 \%)$ humeri\{frequency moreon left side as $(n=24)$ \}.

Table 3: Frequency oftranslucent and opaque septum in humeri.

\begin{tabular}{|c|c|c|}
\hline Parameter & $\begin{array}{c}\text { Right } \\
\text { (N without STF =34) }\end{array}$ & $\begin{array}{c}\text { Left } \\
\text { (N without STF = 36) }\end{array}$ \\
\hline $\begin{array}{c}\text { Translucent } \\
\text { septum }\end{array}$ & $18(52.94 \%)$ & $12(33.33 \%)$ \\
\hline $\begin{array}{c}\text { Opaque } \\
\text { septum }\end{array}$ & $16(47.06 \%)$ & $24(66.66 \%)$ \\
\hline
\end{tabular}

In the present study, the mean vertical diameter (V.D.) for STF was observed to be $3.79 \pm 0.68 \mathrm{~mm}$ (range $2.68-4.73 \mathrm{~mm}$ ) on the right side and $3.94 \pm 1.40 \mathrm{~mm}$ (range $1.4-5.12 \mathrm{~mm}$ ) on the left side.

Transverse diameter ( T.D.) was found to be $5.14 \pm 1.165 \mathrm{~mm}$ (range $2.82-6.17 \mathrm{~mm}$ ) on the right side and $5.21 \pm 2.13 \mathrm{~mm}$ (range $1.52-8.28 \mathrm{~mm}$ ) on the left side.( Table:4)

Table 4: M orphometricmeasurements as T.D. and V.D.

\begin{tabular}{|c|c|c|}
\hline Parameter & Right & Left \\
\hline Mean T.D. \pm S.D & $5.14+1.165 \mathrm{~mm}$ & $5.21+2.13 \mathrm{~mm}$ \\
\hline Mean V.D. \pm S.D & $3.79 \pm 0.68 \mathrm{~mm}$ & $3.94 \pm 1.40 \mathrm{~mm}$ \\
\hline
\end{tabular}

\section{DISCUSSION}

The incidence of STF ranges from $0 \%$ to almost $60 \%$ among different groups of human population [9]. Different races exhibit wide variations in the incidence depending upon the race and sample size studied.

STF is often found in primates and thus considered as an atavistic character. Lamb suggested mechanical stress hypothesis in the 
resorption of the septum at the point of contact of the coronoid or olecranon process of ulna with humerus as a leading factor in the formation of STF such as impact pressure in cases of hyperflexion or hyper-extension at elbow joint [13,14]. Present study showed an incidence of STF as $30 \%$ which is in conformity with the reports of Akabori [15] in M exicans, Ananthi et al [16] and Bhanu et al [9] and more than stated in the reports of Benfer et al [17], Trotter [18], Mays [14] and less as reported by Akabori [15] in Australians \& Egyptian races. Singhal $S$ et al [3] and Anupama Mahajan [8] reported the incidence to be $28 \%$ and $26 \%$ respectively. Earlier studies showed an incidence of $27.4 \%$ in Eastern Indians, 32\% in Central Indians, 27.5\% in North Indians, 28\% in South Indians and 34.4\% in overall Indians [9].

Table 5: Comparative data of STF in humerus, population wise.

\begin{tabular}{|c|c|c|c|}
\hline s.no. & Author & Population & STF \% \\
\hline 1 & Akabori(15) & Australians & 46.5 \\
\hline 2 & Akabori(15) & Egyptians & 43.9 \\
\hline 3 & Akabori(15) & Mexicans & 30.7 \\
\hline 4 & Anupama M(8) & North Indians & 26 \\
\hline 5 & Singhal\&Ra0(3) & South Indians & 28 \\
\hline 6 & Ananthi et al(16) & Indians & 31.3 \\
\hline 7 & Benfer et al(7) & Americans & 6.9 \\
\hline 8 & Bhanu(9) & Indians & 30.5 \\
\hline 9 & Trotter (18) & American Africans & 12.6 \\
\hline 10 & Trotter (18) & American whites & 4.3 \\
\hline 11 & Mays (14) & English & 6.9 \\
\hline 12 & Hima(6) & Eastern Indians & 27.4 \\
\hline 13 & Kate (1) & Central Indians & 32 \\
\hline 14 & Kate (1) & Overall Indians & 34.4 \\
\hline
\end{tabular}

Present study showed round shape $(60 \%)$ in majority of foramens and oval shape in $40 \%$ of cases. Veerappan $V$ et al (19) reported oval shape in $42.85 \%$, round shape in $37.71 \%$, triangular shape in $14.28 \%$ and sieve like in $7.14 \%$. JadhavM ayuri et al (20) reported oval shape in $48.38 \%$, round shape in $41.93 \%$, triangular in $6.45 \%$ and sieve like in $3.22 \%$. There wasn't observed any triangular or sieve like shaped foramen in the present study.
Table 6: Comparison of different shapes of STF (in \%).

\begin{tabular}{|l|c|c|c|c|c|}
\hline S.no. & Authors & Oval \% & Round \% & Triangular \% & Sieve like \% \\
\hline 1. & Veerappan et al(19) & 42.85 & 37.71 & 14.28 & 7.14 \\
\hline 2. & JadhaYM ayuri et al(20) & 48.38 & 41.93 & 6.45 & 3.22 \\
\hline 3. & Present study & 40 & 60 & 0 & 0 \\
\hline
\end{tabular}

Translucent septum was observed in $42.85 \%$ cases in the present study which is less when compared with the reports of SoubhagyaNayak et al (9) (56.7\%), Patel et al (21) (52.5\%), Veerappan V et al (19) (50\%) , AnupamaM ahajan (8) $(62 \%)$ andmore as reported byJadhav Mayuri(20). The current study showed translucent septum chiefly on the right side $(60 \%)$ than the left side (40\%).This finding is in accordance with the reports of Vasantbhai (22) (50\% on the right side ) andVeerappan et al (19) (55.8\% on the right side) whereas it is contradictory to those reported by Bhanu et al (9)and Krishnamurthy et al(23).

Table7: Comparison of presence of translucent septum in humerus in different studies.

\begin{tabular}{|c|c|c|c|}
\hline S,no. & Author & $\begin{array}{c}\text { Predominantsideforpresenc } \\
\text { e of translucent septum }\end{array}$ & Percentage (\%) \\
\hline $\mathbf{1}$ & Bhanu et al(19) & Left & $82.14 \%$ \\
\hline $\mathbf{2}$ & Krishnamurthy et al(23) & Left & $66.60 \%$ \\
\hline $\mathbf{3}$ & Vasantbhai(22) & Right & $50 \%$ \\
\hline $\mathbf{4}$ & Veerappan et al(19) & Right & $55.80 \%$ \\
\hline $\mathbf{5}$ & Present study & Right & $52.94 \%$ \\
\hline
\end{tabular}

Opaque septum was recorded more on left side $(60 \%)$ as compared to right side $(40 \%)$ and this fact differs from other studies [3,24].

In the current study, the vertical diameter for STF was observed as $3.79 \pm 0.68 \mathrm{~mm}$ on the right side and $3.94 \pm 1.40 \mathrm{~mm}$ on the left side. Transverse diameter was found to be $5.14 \pm 1.165$ $\mathrm{mm}$ on the right side and $5.21 \pm 2.13 \mathrm{~mm}$ on the left side. The mean TD of STF on the left side is observed to be slightly larger than on the right side, as is also reported by Ozturk et al [25] and Erdogmus $S$ et al [26]. The transverse diameters of both sides were observed to be more than the vertical diameter which is similar with the studies of Nayak et al [7] and Bhanuand Shankar [9].

Supratrochlear fracture ofhumerus accounts for $75 \%$ of the total of pediatric age group injuries. Its treatment requires an adequate route of pin entry [21]. The presence of STF at the lower end 
Table 8: Comparative morphometric parameters of STF of humerus in various studies.

\begin{tabular}{|c|c|c|c|c|c|}
\hline S.No. & Authors & Right VD & Right TD & LeftVD & Left TD \\
\hline 1 & Oturk et a[25] & $4.56 \pm 1.37$ & $6.70 \pm 1.91$ & $4.95 \pm 1.60$ & $6.86 \pm \pm .07$ \\
\hline 2 & Erdogmus et al [26] & $4.12 \pm 0.98$ & $5.63 \pm 0.97$ & $4.04 \pm 0.9$ & $6.01 \pm 1.86$ \\
\hline 3 & Nayak et al[7] & 3.81 & 5.99 & 4.85 & 6.55 \\
\hline 4 & Bhanu and Shankar[9] & $5.75 \pm 1.5$ & $6.68 \pm 0.8$ & $4.86 \pm 1.2$ & $6.92 \pm \pm .0$ \\
\hline 5 & Present study & $3.79 \pm 0.68$ & $5.14 \pm 1.165$ & $3.94 \pm 1.40$ & $5.21 \pm .13$ \\
\hline
\end{tabular}

of humerus may cause hindrance in planning out intramedullary humeral nailing procedure in the distal end of humerus, thus establishing the need to have a better anatomical understanding of lower end of humerus [21].

Antegradeintramedullary nailing procedure is preferred over the retrograde procedure in such cases of humerus with STF.

In day to day clinical practice, bone cysts and otherlytic conditions can be seen with the aid of plain radiographs. STF appears as a relative radiolucent area in $\mathrm{X}$-rays and thus may be mistaken as osteolytic or cystic lesion mimicking the 'pseudolesion' [3]. Thus prior anatomical knowledge is must to avoid such false interpretation by radiologists.

The probability of occurrence of STF in humerus should be kept in mind while performing various orthopaedic, surgical and diagnostic procedures. This paper sensitizes clinical practitioner for presence of STF in humerus and thus making wiser decisions.

\section{REFERENCES}

[1]. M eckel JH (1825), cited in Kate BR, Dubey PN. A note on the septal apertures in the humerus of Central Indians. Eastern Anthropologist. 1970;33:270-84.

[2]. Haziroglu RM, Ozer M : A supratrochlear foramen in the humerus of cattle. AnatHistolEmbryol, 1990;19:106-8.

[3]. Singhal S, Rao V. Supratrochlear foramen of the humerus. AnatSci Int.2007;82:105-7.

[4]. De Wilde V, De M aeseneer M, Lenchik Let al. Normal osseous variants presenting as cystic or lucent areas on radiography and CT imaging: a pictorial overview. Eur J Radiol, 2004;51(1):77-84.

[5]. Sahajpal DT, Pichora D. Septal aperture: an anatomic variant predisposing to bilateral low-energy fractures of the distal humerus. Can J Surg, 2006;49(5):363-64.

[6]. Hima BA, Narasinga RB. Supratrochlear foramen-a phylogenýc remnant. International Journal of Basic and Applied Medical Sciences, 2013;3(2): 13032.

Int J Intg M ed Sci 2016;3(4):265-69. ISSN 2394 - 4137
[7]. Nayak SR, Das S, Krishnamurthy A et al. Supratrochlear foramen of the humerus: An anatomicoradiological study with clinical implications. Ups J Med Sci, 2009;114(2):90-94.

[8]. Mahajan A. Supratrochlear Foramen; Study of humerus in North Indians. Professional Medical Journal, 2011;18(1):128-32.

[9]. Bhanu PS, Sankar KD. Anatomical note of supratrochlear foramen of humerus in south costal population of Andhra Pradesh. Narayana Medical Journal, 2012;1(2):28-34.

[10]. Collins MS, Koyama T, Swee RG, Inwards CY. Clear cell chondrosarcoma: radiographic, computed tomographic, and magnetic resonance findings in 34 patients with pathologic correlation. Skeletal Radiol. 2003;32:687-94.

[11]. Ilaslan H, Sundaram M, Unni KK. Solid variant of aneurysmalbone cysts in long tubular bones: giant cell reparative granuloma. AJR Am J Roentgenol. 2003;180:1681-7.

[12]. Diwan RK, Rani A, Chopra J, et al. incidence of supratrochlear foramen of humerus in North Indian population. Biomedical research. 2013;24(1):1425.

[13]. Lamb DS. The olecranon perforation. Am anthropol, 1890;3:159-174.

[14].Mays S. Septal aperture of the humerus in a mediaeval human skeletal population. Am J Phys Anthropol. 2008;136:432-440.

[15]. Akabori E. Septal apertures in the humerus in Japanese, Ainu and Koreans. Am J Phys Anthropol, 1934;18:395-400.

[16]. Ananthi S, M anickam S, Vaithianathan G et al. study of intercondyloid foramen of humerus. Intercondyloid foramen. Rev Arg de AnatClin. 2011;3(1): 32-6.

[17]. Benfer RA, McKern TW. The correlation of bone robusticity with the perforation of coronoidolecranon septum in the humerus of man. AmJ Phys Anthropol. 1966;24(2): 247-52.

[18]. Trotter M. Septal apertures in humerus of American Whites and Negroes American. Am J Phys Anthropol. 1934;19:213-27.

[19]. Veerappan V, Ananthi S, Kannan NG et al. Anatomical and radiological study of supratrochlear foramen of humerus. World J PharmPharmSci, 2013;2(1):313-20.

[20]. Mayuri J, Aparna T, Pradeep P et al. Anatomical study of Supratrochlear foramen of Humerus. Journal of Research in M edical and Dental Science 2013;1(2):33-35.

[21]. Patel SV, Sutaria LK, NayakTV, Kanjiya DP, Patel BM , Aterkar SH. M orphometric study of supratrochlear foramen of Humerus. IJBAR. 2013;04(02);89-92.

[22].Vasantbhai PS. Morphometrýc Study of Supratrochlear Foramen of Humerus. International Journal of Biomedical and Advance Research, 2013;4(2):89-92.

[23]. Krishnamurthy A, Yelicharla AR, Takkalapalli A. Supratrochlear foramen of humerus -a morphometric study. Int J Biol M ed Res, 2011;2(3);829-31. 
[24].Kumar A, Sharma A, Singh P. A study of supratrochlear foramen of Humerus with its clinical implications. The Clinical Researcher. 2010;02(02):58-60.

[25].Ozturk A, Kutlu C, Bayraktar B et al. The supratrochlear foramen in the humerus (Anatomical Study) stTpFak. M ecmuas, 2000;63:7276.
[26].Erdogmus S, Guler M, Eroglu S, Duran N. The Importance of the SupratrochlearForamen of the Humerus in Humans: An Anatomical Study. MedSciM onit, 2014;20:2643-2650.

\section{How to cite this article:}

Bhumica Dang, Vivek S. Malik, Priyanka Parmar. Supratrochlear Foramen: Incidence, Importance and Clinical Implications in North-Indian Population. Int J Intg Med Sci 2016;3(4):265-269. DOI: 10.16965/ijims.2016.113

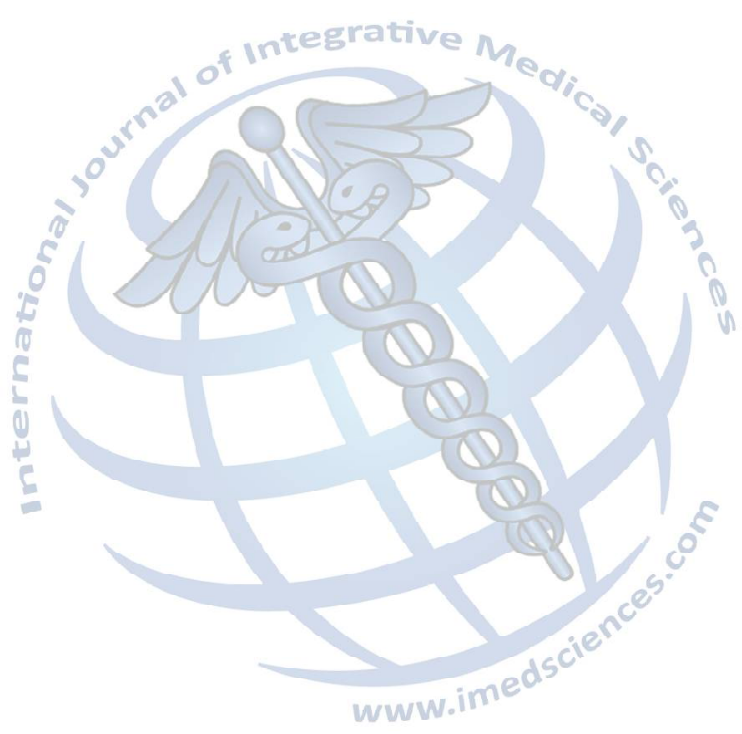

